\title{
Sequence similarity between the viral $c p$ gene and the transgene in transgenic papayas
}

\author{
Manoel Teixeira Souza Júnior(1) and Dennis Gonsalves ${ }^{(2)}$
}

\begin{abstract}
(1)Embrapa Recursos Genéticos e Biotecnologia, Caixa Postal 02372, CEP 70770-900 Brasília, DF, Brazil. E-mail: msouza@cenargen.embrapa.br (2) Cornell University, Department of Plant Pathology, Barton Laboratory, NYSAES, 14.456, Geneva, NY, USA. E-mail: dgonsalves@pbarc.ars.usda.gov
\end{abstract}

\begin{abstract}
The Papaya ringspot virus (PRSV) coat protein transgene present in ‘Rainbow' and 'SunUp’ papayas disclose high sequence similarity ( $>89 \%$ ) to the $c p$ gene from PRSV BR and TH. Despite this, both isolates are able to break down the resistance in 'Rainbow', while only the latter is able to do so in 'SunUp'. The objective of this work was to evaluate the degree of sequence similarity between the $c p$ gene in the challenge isolate and the $c p$ transgene in transgenic papayas resistant to PRSV. The production of a hybrid virus containing the genome backbone of PRSV HA up to the Apa I site in the NIb gene, and downstream from there, the sequence of PRSV TH was undertaken. This hybrid virus, PRSV HA/TH, was obtained and used to challenge 'Rainbow', 'SunUp', and an R2 population derived from line 63-1, all resistant to PRSV HA. PRSV HA/TH broke down the resistance in both papaya varieties and in the 63-1 population, demonstrating that sequence similarity is a major factor in the mechanism of resistance used by transgenic papayas expressing the $c p$ gene. A comparative analysis of the $c p$ gene present in line 55-1 and 63-1-derived transgenic plants and in PRSV HA, BR, and TH was also performed.
\end{abstract}

Index terms: Carica papaya, potyvirus, resistance, breeding, virus.

\section{Similaridade de seqüência entre o gene $c p$ do vírus e do transgene presente em mamoeiros transgênicos}

\begin{abstract}
Resumo - O gene da capa protéica ( $c p$ ) do vírus da mancha anelar do mamoeiro (Papaya ringspot virus, PRSV), presente nos mamoeiros 'Rainbow' e 'SunUp', tem alta similaridade de seqüência (>89\%) com o gene $c p$ dos isolados PRSV BR e TH. Apesar deste alto grau de similaridade, ambos isolados são capazes de quebrar a resistência observada em 'Rainbow', ao passo que TH quebra a resistência em 'SunUp'. O objetivo deste trabalho foi avaliar o grau de similaridade de seqüência entre o gene $c p$ do vírus desafiante e do transgene em mamoeiros transgênicos resistentes a PRSV. Produziu-se um vírus híbrido contendo o genoma do isolado PRSV HA até o sítio de restrição Apa I no gene NIb, e, a partir deste ponto, este vírus continha o genoma do isolado PRSV TH. PRSV HA/TH foi utilizado para desafiar plantas de ‘Rainbow', 'SunUp' e de uma população R2 derivada da linha 63-1, todas resistentes a PRSV HA. PRSV HA/TH quebrou a resistência em todas essas plantas, demonstrando que a similaridade da seqüência é um fator preponderante no mecanismo de resistência utilizado pelos mamoeiros transgênicos expressando o gene $c p$ de PRSV. Também foi realizada análise comparativa do transgene $c p$ das plantas derivadas das linhas transgênicas 55-1 e 63-1, e do gene $c p$ dos isolados PRSV HA, BR e TH.
\end{abstract}

Termos para indexação: Carica papaya, potyvirus, resistência, melhoramento, vírus.

\section{Introduction}

Papaya ringspot is the most outstanding virus disease of Carica papaya L. Papaya ringspot virus (PRSV), type strain $\mathrm{P}$, is the causal agent of papaya ringspot. PRSV is transmitted to papaya and members of the Cucurbitaceae family by numerous species of aphids in a non-persistent mode. It is a definitive species of the Potyvirus genus from Potyviridae family, and it presents flexuous rod-shaped particles of 780x12 nm and a genome consisting of positive single stranded RNA (Purcifull et al., 1996).

The complete genome sequence of two PRSV isolates are available, and the genomic RNA, excluding the poly (A) tract, is 10,326 nucleotides long and discloses one open reading frame that encodes a polyprotein of 3,344 amino acids (Yeh et al., 1992; Wang \& Yeh, 1997). 
The control of PRSV was ventured at through many approaches, such as sanitation programs, genetic resistance, cross protection, natural tolerance, and transgenic plants (Souza Junior \& Gonsalves, 1999). Before the advent of the transgenic plants, no other approach had provided a highly effective control of this disease. First $c p$ transgenic papaya varieties resistant to PRSV, varieties Rainbow and SunUp were highly resistant to the Hawaiian isolates of PRSV, but showed limited effectiveness against some isolates from other regions (Gonsalves, 1998). Experimental results so far have suggested that the $c p$ gene-mediated resistance observed in transgenic papayas is a case of RNAmediated protection (Tennant et al., 2001), a mechanism most likely due to post-transcriptional gene silencing (PTGS) (Boogaart et al., 1998).

Infectious transcripts enable plant virologists to perform studies of the genetics of RNA viruses by mutagenesis, insertion, and deletions, and by complementation experiments. It can also be used in studies of natural or induced RNA recombination, of mechanisms generating defective-interfering RNAs or satellite RNAs, and of mechanisms of virus movement within the host or between hosts (Boyer \& Haenni, 1994). Infectious transcripts have also been used in studies of the mechanisms dictating genetically engineered resistance to plant virus diseases (Marano \& Baulcombe, 1998). A major breakthrough for investigation of transgenic papaya was achieved by the production of pPRSV HA (Chiang \& Yeh, 1997), an in vitro transcription clone that has the entire genome of the severe PRSV HA isolate inserted downstream the bacteriophage T3 RNA promoter that is able to produce infectious transcripts of this virus (Gonsalves \& Ishii, 1980).

The objective of the present study was to look at the role of viral sequence similarity in the resistance to PRSV observed in transgenic papayas expressing the $c p$ gene of this virus.

\section{Material and Methods}

At first, it was assumed that a closer analysis of the DNA sequence used to produce the transgenic papayas (Fitch et al., 1992) and the corresponding $c p$ gene sequences from the homologous PRSV HA, and the heterologous PRSV BR and TH, could help to better understand this isolate-specific resistance (Tennant et al., 1994). The second approach was the development of
pPRSV HA-derived hybrid infectious transcripts containing the $c p$ gene of PRSV TH replacing PRSV HA's $c p$ gene. This hybrid virus would then be used to challenge PRSV HA-resistant papaya plants in order to determine whether these nucleotide sequence divergences could result in the break down of resistant to PRSV HA.

\section{Reverse transcription-polymerase chain reaction, and cloning of RT-PCR products}

A RT-PCR product from PRSV TH, consisting of the last 283 nucleotides (nt) from the NIb gene (downstream nt 8912 from PRSV HA), the entire $c p$ gene, the entire 3 ' non-coding region (ncr), and a stretch of the poly (A) tract was obtained. Total plant RNA from PRSV infected papaya plants was extracted as described by Napoli et al. (1990). The RT was performed under the following conditions: 1-2 $\mu \mathrm{g}$ of total RNA, 200 ng of Not I primeradaptor (Promega, Madison, WI), 200 ng of each dNTPs, $10 \mathrm{mM}$ DTT, 80 units of RNAsin, $360 \mathrm{mM}$ of 2-mercaptoethanol, 1X RT buffer, and 400 units of M-MLV RT. Initially, a $15 \mu \mathrm{L}$ aliquot containing only the total RNA and the Not I primer-adaptor was heated at $70^{\circ} \mathrm{C}$ for $5 \mathrm{~min}$, and cooled on ice for $2 \mathrm{~min}$. Then, a $35 \mu \mathrm{L}$ aliquot containing the other reaction components was added and incubated for $90 \mathrm{~min}$ at $37^{\circ} \mathrm{C}$. After that, the sample was incubated at $70^{\circ} \mathrm{C}$ for 5 min to stop the reaction. Five $\mu \mathrm{L}$ of $\mathrm{RT}$ solution with single strand cDNAs were used as template for PCR under the following conditions: $100 \mathrm{ng}$ of each dNTP, $1 \mathrm{X}$ TaqPlus Long low salt buffer, 100 ng of the primer 5'- GCT GGG CCC CAT ATG TGT CTG -3', an equal amount of the Not I primer-adaptor, and 2.5 units of TaqPlus Long polymerase (Stratagene, La Jolla, CA.) per tube, in a $50 \mu \mathrm{L}$ final volume. A cycle of $94^{\circ} \mathrm{C}$ for $3 \mathrm{~min}, 50^{\circ} \mathrm{C}$ for $1 \mathrm{~min}$, and $72^{\circ} \mathrm{C}$ for 3 min was followed by 25 cycles of $92^{\circ} \mathrm{C}$ for $1 \mathrm{~min}, 52^{\circ} \mathrm{C}$ for $1 \mathrm{~min}$, and $72^{\circ} \mathrm{C}$ for $3 \mathrm{~min}$, and by a cycle of $72^{\circ} \mathrm{C}$ for $7 \mathrm{~min}$. The PCR products were separated by $1 \%$ agarose gel electrophoresis buffered in $1 \mathrm{X}$ TAE and stained with ethidium bromide (Sambrook et al., 1991). The RT-PCR product from PRSV TH was cloned in vector pCR ${ }^{\circledR} 2.1$ (Invitrogen, Carlsbad, CA.) as described by manufacturer, generating a clone hereafter named pCP(TH).

\section{Production of PRSV hybrid virus}

The pPRSV HA Apa I-Not I restriction fragment, containing the last 136 nucleotides in the NIb gene 3'-end (from nucleotide 9060 to 9195) (Yeh et al., 1992), the entire $c p$ gene (924 nucleotides), the entire 3'-ncr 
(206 nucleotides), and the 36 nucleotides long poly (A) tail were removed and replaced by the Apa I-Not I digested RT-PCR fragment amplified from PRSV TH, containing the respective virus sequence, generating pPRSV HA/TH. Apa I-Not I restriction fragment was separated by electrophoresis in 1.5\% low melting agarose gel buffered in 1X TAE (Sambrook et al., 1991), stained with ethidium bromide, and purified from the gel using Prep-A-Gene ${ }^{\circledR}$ DNA Purification System (Bio-Rad Laboratories, Hercules, CA). A 3:1 insert:vector ratio was used for the ligation reaction.

In vitro transcription of Not I-linearized pPRSV HA and pPRSV HA/TH (30 $\mu \mathrm{g}$ in $200 \mu \mathrm{L}$ final volume) was carried out with the mCAP ${ }^{\mathrm{TM}} \mathrm{RNA}$ Capping kit (Stratagene, La Jolla, CA.), T3 RNA polymerase (1.2 units per $\mu \mathrm{L}$ ), RNasin (0.4 unit per $\mu \mathrm{L}$ ), and 500 mM m7GpppG (New England Biolabs, Bervely, MA). The mixture was first incubated at $37^{\circ} \mathrm{C}$ for one hour. GTP was then supplemented to $250 \mathrm{mM}$ and the incubation was allowed to proceed for another hour. In vitro transcripts from linearized pPRSV HA and pPRSV HA/TH were diluted once in sterile cold $0.01 \mathrm{M}$ potassium phosphate (pH 7.5), and without further treatment were used for infectivity assays. Transcripts were mechanically inoculated to non-transformed 'Sunrise' papaya plants at the 4-6 true-leaf stage. Two aliquots of $50 \mu \mathrm{L}$ each infectious transcript were mechanically applied onto two carborundum-dusted papaya leaves with a sterilized pestle, one aliquot per leaf. Inoculated leaves were rinsed with distilled water, and plants were put in greenhouse condition covered with newspaper for two days. After inoculation, plants were monitored in the greenhouse up to six weeks for symptom development.

\section{Plant material}

The transgenic lines 55-1 and 63-1 were derived from the red-flesh 'Sunset' papaya by biolistic-mediated transformation with the $c p$ gene of the mild strain PRSV HA 5-1 (Yeh \& Gonsalves 1984; Fitch et al., 1992). Line 55-1 contains a single $c p$ transgene insertion (Tennant et al., 1994), while 63-1 contains a double insertion (Souza Junior, 1999). Both 'SunUp' and 'Rainbow' papaya were derived from line 55-1. 'SunUp' is line 55-1 that is homozygous for the single $c p$ transgene, while 'Rainbow' is an $F_{1}$ hybrid between 'SunUp' and the yellow-fresh 'Kapoho'.

The fact that 63-1 Ro was a hermaphrodite plant made possible the production of an R1 population by self- pollination. The R2 population C2 was obtained by selfpollination of P07, a 63-1 R1 plant selected as resistant to PRSV BR by mechanical inoculation (Souza Junior, 1999). The 63-1 R2 population C2 was obtained in the greenhouse at the New York State Agricultural Experiment Station (NYSAES) in Geneva, NY.

In order to achieve uniform germination, seeds were treated in $1 \mathrm{M}$ potassium nitrate for 30 minutes under constant agitation (Nagao \& Furutani, 1986), and then further treated with Captan $\left(0.1 \%\right.$ in $\left.1 \mathrm{M} \mathrm{KNO}_{3}\right)$ for 2-5 minutes. Seeds were germinated under greenhouse conditions in pots containing a soil:vermiculite:perlite mixture (1:1:1 by volume). The seedlings were transferred to individual pots containing the same mix described above, and kept in the greenhouse for the duration of the experiment.

\section{Virus isolates and plant inoculation}

Besides the hybrid virus, two other PRSV isolates were used in this study, PRSV HA and TH. Both isolates came from the PRSV bank of isolates at NYSAES, in Geneva, NY. The isolates were maintained in the greenhouse in C. papaya and Cucumis metuliferus L. Symptomatic leaves of C. metuliferus infected with individual PRSV isolate were used as inocula. Transgenic and nontransgenic plants, after being dusted with carborundum powder, were mechanically inoculated by rubbing off a 1:20 (w:v) sap of infected leaves macerated in cold $0.01 \mathrm{M}$ potassium phosphate (pH 7.5). Two leaves were inoculated per plant. Inoculated leaves were subsequently rinsed with water. Plants were inoculated once and observed for symptoms development weekly for a period of three weeks. Then, the symptomless plants were reinoculated and observed weekly for three more weeks. The response to virus inoculation was assessed by comparing the rate of symptom development (vein clearing, mosaic, leaf distortion, leaf reduction) and the severity of symptoms on new growth of transgenic and nontransgenic plants.

\section{DNA sequencing and sequences analysis}

Plasmid DNA, purified accordingly to a modified mini alkaline-lysis/PEG precipitation procedure (Souza Junior, 1999), was sequenced using a DNA sequencing system with Taq Dye terminator chemistry at the DNA Sequencing Services-Biotechnology Building (Ithaca, NY) or at Department of Entomology-Barton Lab.NYSAES (Geneva, NY). The $c p$ gene of PRSV BR is $921 \mathrm{nt}$ long, three nt shorter than the $c p$ gene from PRSV HA. Nucleotides corresponding to positions 
133-135 of PRSV HA are missing in the Brazilian isolate. Sequences of the $c p$ gene from the Jamaican and Thailand isolates of PRSV were obtained from Tennant (1996). Alignments analyses were done using the Clustal method-Megalign software (DNA DNASTAR INC., 2004).

\section{Results and Discussion}

Both lines 55-1 and 63-1 were produced by biolisticmediated transformation using the Agrobacterium-binary vector pGA482GG/cpPRV-4 (Fitch et al., 1992). The $c p$ gene present in this DNA construction was derived from the mutant mild strain PRSV HA 5-1 (Yeh \& Gonsalves, 1984). However, the first 56 nucleotides in the 5'-end of the $c p$ gene is absent in this construction (Yeh et al., 1992). Therefore, the following sequence analysis considers the last 865 nucleotides in the $c p$ gene, upstream of the stop codon. PRSV TH was the most distantly related to PRSV HA 5-1 showing about $89.3 \%$ of similarity at the nucleotide sequence analyzed, followed by the Brazilian isolate (92.6\%) and the Hawaiian isolate (99.8\%) (Figure 1). Only two nucleotides were different between PRSV HA and PRSV HA 5-1, as already pointed by Chiang et al. (2001).

The $c p$ gene of PRSV could be divided in three regions, $\mathrm{N}$ terminus (first 224 nucleotides), $\mathrm{C}$ terminus (last 59 nucleotides, including the stop codon), and core (641 nucleotides between the $\mathrm{N}$ and the $\mathrm{C}$ terminus), as suggested for other potyvirus (Shukla \& Ward, 1989; Bateson et al., 1994). The analysis of the divergence between PRSV HA 5-1 and the Brazilian isolate throughout these three regions revealed that divergence is concentrated in the $\mathrm{N}$ terminus (21 nucleotides different) and core (36 nucleotides different) regions; nucleotide differences were not seen in the $C$ terminus region. When comparing PRSV HA 5-1 and the Thai isolate, the same level of difference was seen in the $\mathrm{N}$ terminus (22 nucleotides), a much higher level of difference was seen in the core (60 nucleotides), and three nucleotides diverged in the $\mathrm{C}$ terminus. A stretch of 49 nucleotides, belonging to the 3'-ncr of PRSV, was also present in pGA482GG/cpPRV-4 immediately downstream of the $c p$ stop codon. An alignment analysis of this stretch from PRSV HA 5-1 and its counterpart in PRSV HA, PRSV BR, and PRSV TH, revealed a $100 \%, 88 \%$, and $88 \%$ nucleotide similarity, respectively. The latter accounted to differences in six out of
49 nucleotides between PRSV HA 5-1 and the Brazilian or Thai isolates.

The construction pCP(TH) was partially sequenced from both ends using the universal vector primers M13 in order to verify the presence of the Apa I restriction site at the 3 '-end of the $N I b$ gene, and to check the size of the poly (A) amplified. The poly (A) track obtained in $\mathrm{pCP}(\mathrm{TH})$ was 35 nucleotides long. After obtaining and characterizing pCP(TH), the Apa I-Not I digested RTPCR fragment amplified from PRSV TH was removed and inserted in the pPRSV HA Apa I-Not I restriction fragment, generating the hybrid construction, pPRSV HA/TH. In order to confirm its accuracy, pPRSV HA/TH was partially sequenced using primer 5' - CTAAGC TTC TAG AGC ATC GAT TGG AGG 3', which anneals upstream the annealing site for 5'- GCT GGG CCC CAT ATG TGT CTG -3', the 5'-primer used to amplify the Apa I-Not I RT-PCR fragment from PRSV TH. As expected, the construction

Figure 1. Sequence pair distances calculated by the Clustal method of Megalign software between the $c p$ transgene present in the genome of transgenic papaya lines 55-1 and 63-1 and three PRSV isolates with differential response when challenging 'Rainbow' and 'SunUp' papayas. This analysis compared only the 865 nucleotides upstream of the stop codon. Degree of similarity in percentage is given in the upper part, and the degree of divergence is given in the down part.

\begin{tabular}{|c|c|c|c|c|}
\hline $\begin{array}{c}\text { PRSV } \\
\text { Isolates }\end{array}$ & HA 5-1 & HA & BR & TH \\
\hline HA 5-1 & & 99.8 & 92.6 & 89.3 \\
\hline HA & 0.2 & & 92.8 & 89.6 \\
\hline BR & 6.6 & 6.4 & & 88.7 \\
\hline TH & 10.5 & 10.2 & 11.8 & \\
\hline
\end{tabular}


showed the transition from PRSV HA genome to PRSV TH genome at the Apa I site in the NIb gene.

In vitro transcription reactions were performed twice for both constructions, pPRSV HA (positive control) and pPRSV HA/TH. Agarose gel electrophoresis analysis of the in vitro reaction revealed the presence of RNA transcripts with similar size in both treatments (Figure 2). Totally, five 'Sunrise' plants were inoculated with each of the RNA transcripts, and the plants were monitored for symptom development for up to six weeks after inoculation. Three out of five plants inoculated with transcripts from pPRSV HA developed symptoms between two to three weeks after the inoculation, showing an incubation period very close to the one observed when virions particles of PRSV are used to infect a papaya plant. Two out of five plants inoculated with transcripts from pPRSV HA/TH developed

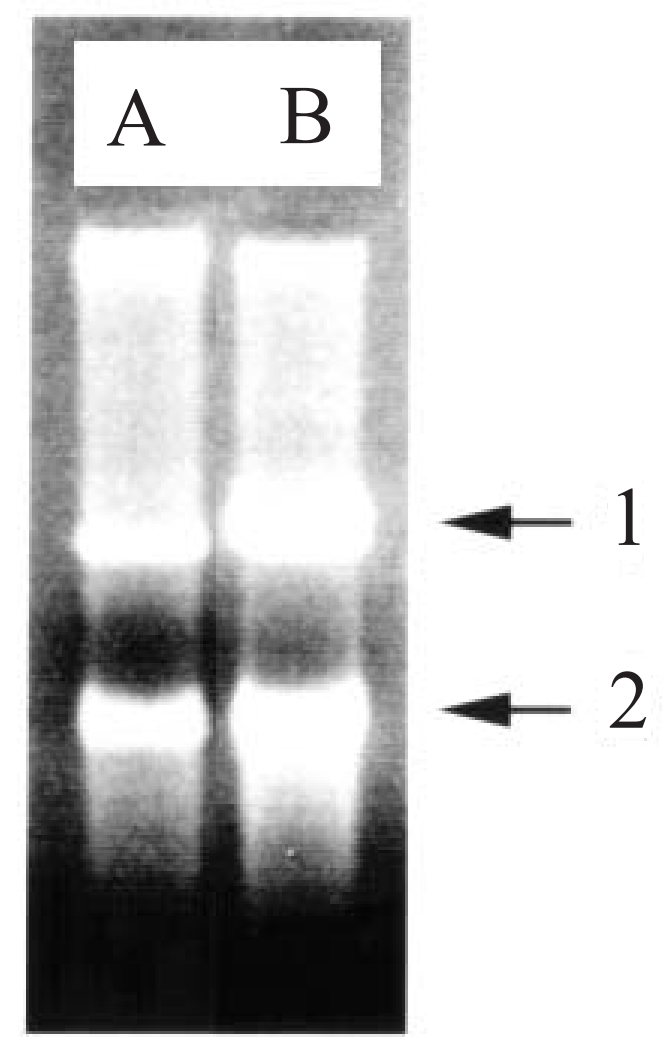

Figure 2. In vitro transcription of pPRSV clones to produce PRSV infectious transcripts. A: pPRSV HA; B: pPRSV HA/TH. Gel shows both the linear Not I-digested pPRSV DNA (1) and the RNA transcript (2) yield after in vitro transcription with T3 RNA polymerase. symptoms (one from each of the in vitro transcription reactions performed). However, these two plants showed a two-week-delay in symptom development, appearing four to five weeks after inoculation of pPRSV HA/TH RNA transcripts.

The incubation period observed when using pPRSV HA/TH RNA transcripts was reduced to the normal two weeks period after two rounds of PRSV HA/ TH inoculation in papaya and C. metuliferus plants. The severity of the symptoms observed from the inoculation of non-transformed plants with PRSV HA/TH was very similar to the one observed when using PRSV HA. The hybrid virus PRSV HA/TH from the first in vitro transcription reactions performed was chosen for analysis of infectivity in transgenic plants.

Before the analysis of infectivity in transgenic plants, the hybrid virus PRSV HA/TH was submitted to RTPCR as described above (using primer 5'- CTA AGC TTC TAG AGC ATC GAT TGG AGG -3' as 5'-end primer). The RT-PCR product was cloned in $\mathrm{PCR} \AA 2.1$, generating clone $\mathrm{pCP}(\mathrm{HA} / \mathrm{TH})$. This clone was partially sequenced from the 5'-end using primer 5'- CTA AGC TTC TAG AGC ATC GAT TGG AGG -3', in order to confirm the veracity of the hybrid virus. The identity of PRSV HA/TH was confirmed when $100 \%$ similarity was found between this hybrid virus and the Hawaiian isolate in a genome segment 117 nucleotides long immediately upstream of the Apa I site. A 100\% match was also found between the hybrid virus and the Thai isolate in a genome segment 93 nucleotides long immediately downstream the sequence of the 5'-end primer. As pPRSV HA/TH identity was confirmed, this hybrid virus was used for infectivity assays in transgenic plants.

The results of the challenge of 'Rainbow' and 'SunUp' papayas with the hybrid virus are shown in Table 1. Those results are the sum of two similar experiments initiated two weeks apart. All 'Rainbow' plants were resistant to the PRSV HA and susceptible to PRSV TH. The hybrid virus was able to breakdown the resistance in all 'Rainbow' plants tested. All 'SunUp' plants were resistant to PRSV HA, while only $44 \%$ of the plants became infected when challenged by PRSV TH. The hybrid virus was able to break down the resistance in $30 \%$ of the 'SunUp' plants. The low percentage of 'SunUp' plants symptomatic after challenge by the Thai isolate is believed to result from the fact that the plants inoculated were older than the normal 6-10 leaf stage regularly used for inoculation. Plant age has been shown 
to be a factor in the resistance in transgenic papayas to PRSV (Souza Junior, 1999; Tennant et al., 2001).

The results of the challenge of a line 63-1-derived population, called $\mathrm{C} 2$, with the hybrid virus are also in Table 1. Those results originated from a single experiment. Again, plants from a population that was $100 \%$ resistant to the homologous PRSV HA turned out to be susceptible to the hybrid virus. Although the hybrid virus overcame the resistance in $87 \%$ of the $63-1$ R2 plants, the severity of the symptoms was much more alleviated than the ones caused by the Thai isolate.

In order to confirm the identity of the hybrid virus breaking down the resistance in 'Rainbow', 'SunUp', and the $\mathrm{C} 2$ population, PRSV HA/TH was collected and submitted to sequencing. A 'SunUp' plant infected by the hybrid virus was used as source of total RNA, and a $\mathrm{pCP}(\mathrm{HA} / \mathrm{TH})$ clone was generated as described above. This clone was also partially sequenced from the 5' end, and the pPRSV HA/TH identity was confirmed.

The results showed that a hybrid virus containing the genome backbone of the homologous isolate PRSV HA, and the 3' end of the NIb gene, plus the $c p$ gene and the 3' non-coding region (ncr) of the heterologous isolate PRSV TH is able to break down the resistance in transgenic 'Rainbow', 'SunUp', and 63-1 papayas. In addition, a closer look at the sequences of the $c p$ transgene in transgenic papayas and the $c p$ gene and the 3'-ncr in the homologous and two heterologous PRSV isolates suggests that the isolate specific response observed is unlikely to result only from the nucleotide differences found at the 3'-end of the transgene.

PRSV HA was able to support a major modification in its genome. The replacement of its last

Table 1. Challenge of transgenic papaya plants with the hybrid virus PRSV HA/TH and its parental PRSV isolates (PRSV HA and PRSV TH). Results are shown as number of symptomatic plants per number of inoculated plants. Responses of Rainbow and SunUp to mechanical inoculation by PRSV HA/TH, PRSV HA, and PRSV TH are the sum of two experiments. Response of the 63-1 R2 C2 population is from one experiment. Non-transgenic 'Sunrise' was used as control.

\begin{tabular}{lccc}
\hline Papaya cultivar & \multicolumn{3}{c}{ PRSV Isolate } \\
\cline { 2 - 4 } or population & HA & TH & HA/TH \\
\hline Sunrise & $6 / 6$ & $6 / 6$ & $6 / 6$ \\
Rainbow & $0 / 9$ & $9 / 9$ & $9 / 9$ \\
SunUp & $0 / 9$ & $6 / 6$ & $3 / 9$ \\
63-1 R2 C2 & $0 / 30$ & $30 / 30$ & $26 / 30$ \\
\hline
\end{tabular}

1,266 nucleotides immediately upstream the beginning of the poly (A) tail by the counterpart sequence in PRSV TH produced a viable and infectious hybrid virus, PRSV HA/TH. The severity of the symptoms caused by the hybrid virus was visually similar to the one caused by PRSV HA, and weaker than PRSV TH, suggesting that whatever cis factors are responsible for the manifestation of the virulence, these factors are likely to be concentrated outside the replaced sequence cited above.

The results show that the sequence differences in the $c p$ gene of PRSV isolates are a major factor in the resistance seen in transgenic papayas. Even though such a high percentage of similarity is seen among these $c p$ gene sequences, a major change in the fate of the interaction was seen when the $c p$ gene from the Hawaiian isolate was replaced by the Thai isolate. A compatible interaction replaced an incompatible one between 'Rainbow' and PRSV HA when the $c p$ gene of the Thai isolate was expressed in a PRSV HA genome background. The same change in response was seen when using 'SunUp' and the 63-1-derived population C2.

Some studies have tried to map the sequence(s) targeted for degradation in a transgene under PTGS, which seems to be the case of the PRSV $c p$ transgene in 'Rainbow' and 'SunUp' papayas (Tennant et al., 2001). In two studies, by English et al. (1996) and Sijen et al. (1996), this region was mapped to the 3'-end of the transgene. Sijen et al. (1996) used recombinant Potato $\mathrm{x}$ virus (PVX) to challenge resistant plants expressing a full-length movement protein gene and observed that the resistance against Cowpea mosaic virus (CPMV) was effective against target sequences as short as 60 nucleotides. The alignment of the last 150 nucleotides in the 3 '-end of the $c p$ transgene present in lines 55- 1 and 63-1 (including the 49 nucleotides from the 3'-ncr) with its counterparts in PRSV BR and PRSV TH reveals a very high sequence similarity among these sequences. Only six nucleotides out of the 150 considered are different in the Brazilian isolate, while the Thai isolate shows 11 different nucleotides.

When considering only the last 52 nucleotides, which includes the stop codon and the 3'-ncr, both Brazilian and Thai isolates had only six nucleotides different from the sequence in the transgenic lines. Goodwin et al. (1996), using primer extension analysis, identified two target sites about 120 nucleotides apart in the middle part of the Tobacco etch virus (TEV) cp gene. Marano 
\& Baulcombe (1998) also identified multiple target regions when studying RNA-mediated resistance in tobacco plants expressing the 54-kDa open reading frame (ORF) of TMV-U1. Jan (1998) suggested that several target sites would be spread throughout the entire transgene. The differences in sequence homology between the $c p$ transgene in lines 55-1 and 63-1, and its counterparts in the Brazilian and Thai isolates, are higher in the 5'-end and middle part of the transgene, suggesting that these regions would be better candidates to host targeted sites that could account for the differences in response seen.

Chiang et al. (2001) generated several PRSV HA recombinants with various $c p$ segments of the PRSV YK isolate (Wang \& Yeh, 1997), and evaluated then in 'Rainbow', 'SunUp' and non-transgenic papayas, in an approach very close to the one applied in the present study. In that work, the PRSV $c p$ gene was divided in three sections to compare the isolates. The first section comprehended the sequence from the 5'-end (Quemada's site - Quemada et al., 1990) to the Swa I restriction site (267 nucleotides long), the second one extended from the Swa I site to the Eco R1 site (415 nucleotides long), and the last one extended from the Eco R1 site to the stop codon (183 nucleotides long). Considering those three regions designed by Chiang et al. (2001), the divergence between the transgene and PRSV TH $c p$ gene is 36,35 and 14 nucleotides difference, respectively.

When the analysis is done with the Brazilian isolate, the divergence is 28,25 , and 4 , respectively. Chiang et al. (2001) results show that, changing only the 5'-end of the $c p$ gene, until the $S w a$ I site, does not change the fate of the interaction, suggesting that the target sites for degradation is possibly outside that section of the gene. Further versions of PRSV HA/TH, containing smaller replacements than the one in this present study, would be valuable tools to further study the sequence similarity factor.

The results reinforce the idea that the isolate-specific resistance initially seen by Tennant et al. (1994) is due to differences in the $c p$ gene sequence. Although the putative sequence target(s) for degradation in the $c p$ transgene in lines 55-1 and 63-1 is not yet known, the results here presented suggest that it is probably not only located at the 3'-end of the $c p$ transgene. Thus, future work towards genetic engineering resistance to PRSV through PTGS should consider the use of highly conserved nucleotide sequences in the virus genome as a way to diminish the effects of this factor and obtain transgenic plants with broader spectra of resistance.

Once in the field, transgenic papaya plants can theoretically work as a selection pressure in the virus population, creating the conditions for the outbreak of a PRSV isolate with a discrepancy in the $c p$ sequence over the percentage seen so far. Transgene management, in order to increase the spectrum of resistance, can compensate for sequence differences up to about 14\%-15\% in the $c p$ gene (Souza Junior, 1999). The knowledge of the limits of these two factors - amount of nucleotide changes in the $c p$ gene allowed by the virus and sequence compensation by transgene management is of great importance to predict how lasting this resistance to PRSV in transgenic papayas can be.

\section{Acknowledgement}

To Dr. Shyi-Dong Yeh (National Chung Hsing University, Taichung, Taiwan), for providing vector pPRSV HA; to Dr. Richard Manshardt (University of Hawaii at Manoa, Hawaii), for providing seeds of 'Rainbow' and 'SunUp' papayas; to Dr. Paula Tennant, for providing the sequence of the first $71 \mathrm{nt}$ at the 5'-end of the $c p$ gene from the Brazilian isolate of PRSV; to the Asgrow Seed Company, for the sequence of the remaining $850 \mathrm{nt}$ at the 3 '-end of the $c p$ gene from the Brazilian isolate of PRSV.

\section{References}

BATESON, M.; HENDERSON, J.; CHALEEPROM, W.; GIBBS, A.; DALE, J. Papaya ringspot potyvirus: isolate variability and origin of PRSV type P (Australia). Journal of General Virology, v.75, p.3547-3553, 1994.

BOOGAART, T. van den; LOMONOSSOFF, G.P.; DAVIES, J.W. Can we explain RNA-mediated virus resistance by homology-dependent gene silencing? Molecular Plant Microbe Interactions, v.11, p.717-723, 1998.

BOYER, J.C.; HAENNI, A.L. Infectious transcripts and cDNA clones of RNA viruses. Virology, v.198, p.415-426, 1994.

CHIANG, C.H.; WANG, J.J.; JAN, F.J.; YEH, S.D.; GONSALVES, D. Comparative reactions of recombinant papaya ringspot viruses with chimeric coat protein (CP) genes and wild-type viruses on CPtransgenic papaya. Journal of General Virology, v.82, p.28272836, 2001.

CHIANG, C.H.; YEH, S.D. Infectivity assays of in vitro and in vivo transcripts of papaya ringspot potyvirus. Botanical Bulletin of Academia, v.38, p.153-163, 1997. 
DNA DNASTAR INC. Megalin: multiple and pairwise sequence alignment. Disponível em: (http://www.dnastar.com/web/r10.php). Acesso em: 2004.

ENGLISH, J.J.; MUELLER, E.; BAULCOMBE, D.C. Suppression of virus accumulation in transgenic plants exhibiting silencing of nuclear genes. Plant Cell, v.8, p.179-188, 1996.

FITCH, M.; MANSHARDT, R.; GONSALVES, D.; SLIGHTOM, J.; SANFORD, J. Virus resistant papaya plants derived from tissues bombarded with the coat protein gene of papaya ringspot virus. Bio/Technology, v.10, p.1466-1472, 1992.

GONSALVES, D. Control of papaya ringspot virus in papaya: a case study. Annual Review of Phytopathology, v.36, p.415-437, 1998.

GONSALVES, D.; ISHII, I. Purification and serology of papaya ringspot virus. Phytopathology, v.70, p.1028-1032, 1980.

GOODWIN, J.; CHAPMAN, K.; SWANEY, S.; PARKS, T.D.; WERNSMAN, E.A.; DOUGHERTY, W.G. Genetic and biochemical dissection of transgenic RNA-mediated virus resistance. Plant Cell, v.8, p.95-105, 1996.

JAN, F.J. Roles of nontarget DNA and viral gene length in influencing multi-virus resistance through homology-dependent gene silencing. 286p. 1998. Dissertation (Ph.D.) - Cornell University, Ithaca.

MARANO, M.R.; BAULCOMBE, D. Pathogen-derived resistance targeted against the negative-strand RNA of tobacco mosaic virus: RNA strand-specific gene silencing? Plant Journal, v.3, p.537-546, 1998.

NAGAO, M.A.; FURUTANI, S.C. Improving germination of papaya seed by density separation, potassium nitrate, and gibberellic acid. HortScience, v.21, p.1439-1440, 1986.

NAPOLI, C.; LEMIEUX, C.; JORGENSEN, R. Introduction of a chimeric chalcone synthase gene into petunia results in reversible co-suppression of homologous genes in trans. Plant Cell, v.2, p.279290, 1990.

PURCIFULL, D.E.; EDWARDSON, J.R.; HIEBERT, E.; GONSALVES, D. Papaya ringspot virus. In: BRUNT, A.A.; CRABTREE, K.; DALLWITZ, M.J.; GIBBS, A.J.; WATSON, L. (Ed.). Viruses of plants: descriptions and lists from the VIDE database. Wallingford, England: CAB International, 1996. p.874-877.

QUEMADA, H.; L'HOSTIS, B.; GONSALVES, D.; REARDON, I.M.; HEINRIKSON, R.; HIEBERT, E.L.; SIEU, L.C.; SLIGHTOM, J.L. The nucleotide sequences of the 3'-terminal regions of papaya ringspot virus strains W and P. Journal of General Virology, v.71, p.203-210, 1990.
SAMBROOK, J.; FRITSCH, E.; MANIATIS, T. Molecular cloning: a laboratory manual. New York: Cold Spring Harbour Laboratory, 1991. 3v. 1640p.

SHUKLA, D.; WARD, C. Structure of potyvirus coat proteins and its application in the taxonomy of the potyvirus group. Advances in Virus Research, v.36, p.273-314, 1989.

SIJEN, T.; WELLINK, J.; HIRIART, J.B.; KAMMEN, A. van. RNA-mediated virus resistance: role of repeated transgenes and delineation of targeted regions. Plant Cell, v.8, p.2277-2294, 1996.

SOUZA JUNIOR, M.T. Analysis of the resistance in genetically engineered papaya against papaya ringspot potyvirus, partial characterization of the PRSV Brazil Bahia isolate, and development of transgenic papaya for Brazil. 277p. 1999. Dissertation (Ph.D.) - Cornell University, Ithaca.

SOUZA JUNIOR, M.T.; GONSALVES, D. Genetic engineering resistance to plant virus diseases: an effort to control papaya ringspot potyvirus in Brazil. Fitopatologia Brasileira, v.24, p.485-502, 1999.

TENNANT, P.F. Evaluation of the resistance of coat protein transgenic papaya against papaya ringspot virus isolates and development of transgenic papaya for Jamaica. 317p. 1996. Dissertation (Ph.D.) - Cornell University, Ithaca.

TENNANT, P.F.; FERMIN, G.; FITCH, M.M.; MANSHARDT, R.M.; SLIGHTOM, J.L.; GONSALVES, D. Papaya ringspot virus resistance of transgenic Rainbow and SunUp is affected by gene dosage, plant development, and coat protein homology. European Journal of Plant Pathology, v.107, p.645-653, 2001.

TENNANT, P.F.; GONSALVES, C.; LING, K.S.; FITCH, M.; MANSHARDT, R.; SLIGHTOM, J.L.; GONSALVES, D. Differential protection against papaya ringspot virus isolates in coat protein gene transgenic papaya and classically cross-protected papaya. Phytopathology, v.84, p.1359-1366, 1994.

WANG, C.H.; YEH, S.D. Divergence and conservation of the genomic RNAs of Taiwan and Hawaii strains of papaya ringspot potyvirus. Archives of Virology, v.142, p.271-285, 1997.

YEH, S.; GONSALVES, D. Evaluation of induced mutants of papaya ringspot virus for control by cross protection. Phytopathology, v.74, p.1086-1091, 1984.

YEH, S.D.; JAN, F.J.; CHIANG, C.H.; DOONG, T.J.; CHEN, M.C.; CHUNG, P.H.; BAU, H.J. Complete nucleotide sequence and genetic organization of papaya ringspot virus RNA. Journal of General Virology, v.73, p.2531-2541, 1992.

Received on April 2, 2004 and accepted on December 12, 2004 